\title{
How Has Clinical Psychiatry Changed?: A Historical Perspective
}

\author{
Alistalr Burns, Registrar in Psychiatry, Maudsley Hospital, London SE5
}

During some recent research for a project in the history of psychiatry, I had the opportunity of studying the first hundred years' Annual Reports of Glasgow's Gartnavel Royal Mental Hospital dating from 1814. I was struck at how applicable some of the comments were in modern psychiatry and was interested in some of the phraseology used and ideas expressed. Some were quaint, some entertaining and surprisingly few abstruse.

Gartnavel Royal Hospital was opened in 1814 following a public appeal for funds from a local businessman, Robert McNair. Until then facilities in Glasgow for the insane were inadequate, consisting mainly of cells in the city's Town's Hospital. The Glasgow Royal Asylum, as it was then known, was Scotland's fourth Royal Mental Hospital, the others being at Montrose, Aberdeen and Edinburgh. It moved to its present site in the west of the city in 1843 . The Annual Records consist, in general, of a report by the Directors (usually local dignitaries and businessmen) and the Physician Superintendent, a list of statistical tables concerning patients and accounts and, in the later years, reports by the Commissioners in Lunacy on their visits to the Hospital.

Early attitudes are communicated in a report of 1828 : 'We have often had occasion to recommend early recourse to proper treatment in lunacy. Perhaps one impediment to the influence of our recommendation is an opinion that as lunacy is a mental disease, little benefit in the treatment of it can be expected from medicine. The nature of the mysterious connection of mind with matter is confessedly inscrutable.' This seems to set the scene for the next 150 years and their 'mysterious connection' is hardly more explicable today. A liberal attitude to insanity was inchoate, the deshackling of patients having been pioneered by Pinel in France a few years previously, and the whole philosophy of the institution embodied in 'the principle of promoting both the cure and the comfort of the insane'. Voluntary patients are accepted as far back as 1817 , when 'patients who have resided in The Asylum, instead of reflecting on it as a prison, in which penance must be undergone, and punishment suffered, look to it as a place of refuge to which they flee of their own accord whenever they begin to feel themselves in danger'. This seems to accompany the gradual evolution of public opinion: '. . . it is not sufficiently well known that voluntary patients are admitted to any Royal Mental Hospital on making an application by letter to the Board of Lunacy. This comparative absence of legal procedure impresses the patient favourably and goes far to convince him of the truth of a belief already present in his mind that he is the subject of illness amenable to treatment and not of a breach of the law for which he must be compulsorily dealt with.' The Glasgow Herald is reported in 1857, while commenting on a Christmas Carol Concert given to the patients, as saying: 'How different all this from the former plan of treating those mentally diseased! A stranger suddenly transported to this meeting would have with difficulty believed he was in the midst of a large number of people, who a quarter of a century ago, would have been under strict confinement.' Appropriately, the institution is described as 'the portal of hope for all'.

The treatment process described is familiar fodder: 'The great object is to promote cheerful impressions, to encourage healthy ratiocinatism or to stimulate the passive to the exercise of the power of volition and to combine with these such medical and physical treatments as may be necessary to put and keep the wonderful machine of man in order.' Spiritual matters were taken into hand seriously: '. . . while the physical treatment of insanity is of primary importance, moral and intellectual appliances are also brought into play with great advantage. The regular observance of Divine Worship is highly beneficial to many of the patients, by soothing their minds, by withdrawing their attention from their own brooding sorrows or delusions, by purifying their affections and elevating their hopes.' A healthy disregard for drug treatment is in evidence and general management is emphasized with amazing perspicacity: 'Every Asylum physician uses and values drugs when required for general conditions or specific objections but he condemns their use on a mere blind chance of benefit while the pathology of insanity is still so obscure. He has learned that medicines are but a small part of the medical treatment of the insane and that whatever science may yet reveal, removed from familiar surroundings, distraction from morbid thoughts by occupation and amusement, improvement of bodily condition by needful rest, ample diet, fresh air and exercise and the constant sustaining help of healthy moral influences are far more potent for good.'

The early origins of occupational therapy can clearly be seen as far back as 1820: 'To prevent the mind from brooding over morbid impressions, by affording to our patients such means of employment as may serve to engage and arrest attention is an important part of our duty . . . Females of every rank have a ready resource against idleness in their usual domestic employments . . . males of the rank of gentlemen who have learned no craft and who would feel degraded in the humble operations of digging or wheeling, must, for the occupation of their tedious leisure hours depend chiefly on amusements.' One successful treatment, which never became popular, was described in detail: 'It was the case of a man who fractured his skull in several places by repeated blows of a pointed 
coal hammer which he inflicted deliberately on his brow while standing before a looking-glass. Instead of proving fatal, as at first seemed inevitable, the shock and loss of blood proved wonderfully calmative, the recovery was uninterrupted and the patient was discharged, apparently well, within two months after the injury.'

Most entertaining are those sections dealing with the causation of insanity. Extensive lists are provided in the statistical tables, the early ones containing categories such as 'disappointment in love', 'pecuniary losses', 'religious excitement' and 'sun-stroke' (the last item confessed by them to have been diagnosed in January), while the more comprehensive later reports contain 'diseased leg', 'disappointment', 'domestic trials', 'fatigue with children', 'over-anxiety in business', 'over-work', 'excitement of marriage' and 'want of work'. The sophistication of the 1870 s brought main divisions into physical and moral causes-the latter including 'worry and overwork', 'disappointed affection' and 'mental over-exertion'. How boring to have these all replaced by 'life events'. The evils of masturbation do not escape censure and feature over a period of many years: 'all the thoughts of the individual are subordinate to this passion . . . habits of masturbation usually exist in youths of a timid, pious and retiring disposition but again it is possible that this disposition may be the result of the vice . . . the individual becomes absentminded, undetermined and easily discouraged, he has a stupid shamed look and often a half foolish smile.' Numerically, the most important causes considered were 'intemperance, hereditary disposition and previous insanity.' Also thought to blame was life in the mid-1800s, described thus: 'an objectless luxurious life, with frivolous restless excitement, late hours and sensational reading develops a nervous irritability which is but the first step towards instability.'

Day to day psychiatric practice seemed fraught with the same frustrations as today. Refusal to eat was mentioned in 1822: 'One person refused to eat because he imagined that he was going to be executed for the commission of some capital crime and therefore it was quite unnecessary for him to take any more food. Fortunately, he imagined that the Physician was the Judge by whom he had been condemned and by whom a remission of his punishment might be granted. Accordingly, he daily, at the visit, fell on his knees to implore a respite and he was daily respited on condition that he would eat his dinner-which he then ate very heartily.' Another melancholic similarly refused to eat as she was 'pinned in thought'. Asylum life seemed more adventurous, at least for some members of the staff: 'There were several escapes this year (1871) but fortunately with- out any bad result. As there are no walls around the garden and policies [a word used in Scotland to describe "the pleasure grounds around a mansion"] where the patients work, and where hundreds of them walk daily, they can easily get over or through the weak wooden fence. One male patient while walking in the grounds suddenly started off with two attendants in full pursuit. The Asylum is situated about two miles distant from the River Clyde. He got into the river, opposite the village of Govan, and where it is rather broad and deep. Before they could overtake him he boldly swam across the stream and then tried to hide himself in the yard of a shipbuilder. There he was speedily caught by the attendants who had rapidly crossed over in a boat. He was none the worse for his attempt to escape and has not suffered from it since.'

Malingering was recognized in 1817: 'candour compels the Directors to admit that the comfortable accommodation in the Asylum sometimes produces bad effects on fostering habits of indolence and inducing the patients to employ dishonest arts in order to prolong their stay, after they seem fit for resuming their usual labours.' Problems also existed with rehousing: 'A woman who had been well for several months, remained for a month after she was thought fit for going home, on various pretences, the chief one being that her husband could not get a room large enough for both, his present miserable hovel being rather too small for himself; but on inquiry it was discovered that he was in no haste to find a proper place or to take his wife home, which however, he was at last obliged to do, very little to the satisfaction of either.'

Some of the ways our psychiatric forefathers looked at and described disease appear at times quaint, entertaining, or even downright funny. I do not think we can lose sight of their contribution, their ideas influencing, and indeed living on as ours, we ourselves only being part of the evolving picture. The relevance of their observations has remained and at times we may wonder how far we have progressed-this is true of medicine in general and psychiatry in particular. The beauty of studying history is that you can see, in the space of a morning, three generations' contribution to a subject and obtain a comprehensive overview not available to an individual trapped in the time scale of his own professional career. We can perhaps learn from this the ability to stand back and look at ourselves, the way people will in one hundred years time-as the poet Robert Burns (1759-1796) put it in his poem 'To a Louse':

O wad some Pow'r the giftie gie us

To see oursels as others see us! 